\title{
A Method of Estimating Changes in Vapor Concentrations Continuously Generated from Two-Component Organic Solvents
}

\author{
Hajime HoRI, Toru IsHIDAO and Sumiyo IsHIMATSU
}

Department of Environmental Management, School of Health Sciences, University of Occupational and Environmental Health, Japan. Yahatanishi-ku, Kitakyushu, 807-8555, Japan

Abstract : We measured vapor concentrations continuously evaporated from two-component organic solvents in a reservoir and proposed a method to estimate and predict the evaporation rate or generated vapor concentrations. Two kinds of organic solvents were put into a small reservoir made of glass $(3 \mathrm{~cm}$ in diameter and $3 \mathrm{~cm}$ high) that was installed in a cylindrical glass vessel $(10 \mathrm{~cm}$ in diameter and $15 \mathrm{~cm}$ high). Air was introduced into the glass vessel at a flow rate of $150 \mathrm{ml} / \mathrm{min}$, and the generated vapor concentrations were intermittently monitored for up to 5 hours with a gas chromatograph equipped with a flame ionization detector. The solvent systems tested in this study were the methanoltoluene system and the ethyl acetate-toluene system. The vapor concentrations of the more volatile component, that is, methanol in the methanol-toluene system and ethyl acetate in the ethyl acetate-toluene system, were high at first, and then decreased with time. On the other hand, the concentrations of the less volatile component were low at first, and then increased with time. A model for estimating multicomponent organic vapor concentrations was developed, based on a theory of vapor-liquid equilibria and a theory of the mass transfer rate, and estimated values were compared with experimental ones. The estimated vapor concentrations were in relatively good agreement with the experimental ones. The results suggest that changes in concentrations of two-component organic vapors continuously evaporating from a liquid reservoir can be estimated by the proposed model.

Key words : two-component organic solvent, vapor-liquid equilibria, activity coefficient, mass transfer rate.

(Received 16 August 2010, accepted 5 October 2010) 


\section{Introduction}

Organic solvents are widely used as thinners, inks, degreasers and so on. Because organic solvents are volatile liquids, they are easily vaporized into the air. The volatility of solvents depends on their saturated vapor pressure. In general, more volatile solvents have higher saturated vapor pressure, and the vapor concentrations of such solvents may easily become higher in work environments.

Most solvents used in workplaces are not single component but a mixture of several components [1]. When two or more kinds of solvents are mixed and left in a closed vessel, the vapor phase and liquid phase reach a state of equilibrium. The equilibrated vapor concentrations in multicomponent solvents depend on the molar fraction of the liquid solvents in the mixture. Because the physical and chemical properties, such as the saturated vapor pressure and the polarity of pure components, are different from solvent to solvent, fractions of solvents in the liquid phase and in the vapor phase are usually different when a state of equilibrium is established.

We had previously studied the equilibrated vapor concentrations for multicomponent organic solvents experimentally [2] and theoretically[3,4], and found that the equilibrated vapor concentration could be estimated from a model using the Margules equation [3] and UNIFAC equation [4] for estimating the activity coefficient. In actual work environments, however, the vapor concentrations are always lower than their equilibrated concentrations because workplaces are not closed spaces and organic solvents are continuously evaporated into the work environments. Because of the difference in the evaporation rates of solvents, the composition of the solvents in the liquid phase is continuously changing with time, and therefore, the vapor concentrations of each component also change with time.

Recently, enterprises that introduce the Occupational Safety and Health Management System (OSHMS) are increasing. Risk assessment and risk management are important tools of the OSHMS. In order to carry out risk assessment of organic vapors in workplaces, the evaporation rates of multicomponent solvents or vapor generation characteristics should be known. Although several models have been proposed to assess work environments for harmful chemicals [5], there is no model to predict each component of multicomponent organic vapor concentrations in the work environment.

In this study, we investigated the generation characteristics of two-component organic vapors that evaporated from a liquid mixture in a reservoir continuously, and proposed a method of estimating the vapor concentration, using a theory of vapor-liquid equilibria and a theory of mass transfer rate.

\section{Methods}

\section{Experimental apparatus and procedure}

Figure 1 shows a schematic diagram of the experimental apparatus. It consists of a vapor generator 2, 3), a thermostatic bath 4), an auto-gas sampler (GS-5000A, GL Science, Japan) 5) and a 
gas chromatograph equipped with a flame ionization detector (GC) (CG-17A, Shimadzu, Japan) 6 ). The vapor generator consists of a liquid reservoir made of glass $(3 \mathrm{~cm}$ in diameter and $3 \mathrm{~cm}$ high) 2) as an evaporator and a closed glass cylindrical vessel (outer vessel, $10 \mathrm{~cm}$ in diameter and $15 \mathrm{~cm}$ high) 3). Teflon pipe ( $3 \mathrm{~mm}$ in outer diameter) was used for tubing.

Two kinds of different liquid organic solvents were weighed and put into the reservoir, and then it was left in the outer vessel in a thermostatic bath. Organic vapors obtained from the vapor generator were sampled intermittently by the auto-gas sampler, and the vapor concentrations were determined with the GC. The vapor concentrations were monitored up to 5 hours in order to investigate the temporal changes in the vapor concentration. Analytical conditions of the GC are shown in Table 1.

The organic solvents used in this study were methanol (Kanto Chemical, Japan), toluene and ethyl acetate (Wako Chemical, Japan), and mixtures of a methanol-toluene system and an ethyl acetate-toluene system, both of which are major components of thinners, were tested. All solvents used were of the reagent grade.

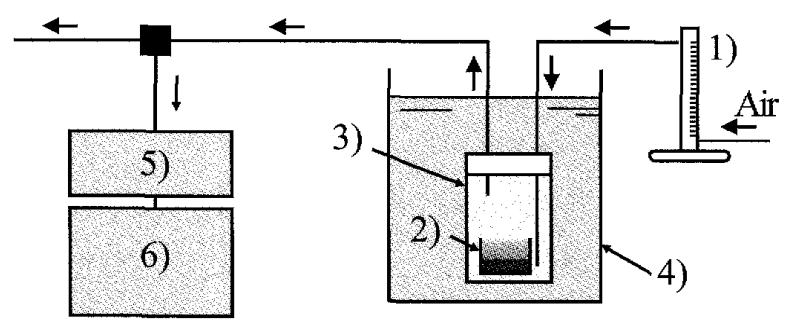

Fig. 1. Schematic diagram of experimental apparatus. 1) Rotameter, 2) Liquid reservoir, 3) Glass vessel, 4) Thermostatic bath, 5) Auto gas sampler, 6) FIDGas chromatograph.

Table 1. Analytical conditions of gas chromatography

\begin{tabular}{ll}
\hline \multicolumn{2}{l}{ Gas chromatograph GC-17A (Shimadzu Corp) } \\
\hline Detector & Flame ionization detector (FID) \\
Column & DB-WAX (J\&W Scientific) capillary column \\
Column length and diameter & $50 \mathrm{~m} \times 0.25 \mathrm{~mm}$ \\
Carrier gas & Nitrogen \\
Carrier gas flow rate & $22 \mathrm{ml} / \mathrm{min}$ \\
Column flow rate & $0.3 \mathrm{ml} / \mathrm{min}$ \\
Column pressure & $60 \mathrm{kPa}$ \\
Column temperature & $100^{\circ} \mathrm{C}$ \\
Injection port temperature & $230^{\circ} \mathrm{C}$ \\
Detector temperature & $230^{\circ} \mathrm{C}$ \\
\hline
\end{tabular}




\section{Theoretical approach for estimation of vapor concentrations}

When a liquid solvent is put into a vessel, it evaporates into the air, and then the amount of liquid in the vessel decreases. The decreasing rate of liquid, that is, the vapor generation rate, is shown as follows using mass transfer coefficient, $\boldsymbol{k}\left(\mathrm{mol} / \mathrm{min} \cdot \mathrm{mm}^{2}\right)$ :

$$
\frac{d n}{d t}=k A\left(C-C^{s a t}\right)
$$

where $\boldsymbol{n}$ is the amount of liquid (mol) in the reservoir, $\boldsymbol{t}$ is the time (min), $\boldsymbol{A}$ is the evaporation area $\left(\mathrm{m}^{2}\right), C$ is the concentration of the vapor (-), and $C^{\text {sat }}$ is the saturated vapor concentration (-).

Eq.(1) is a mass transfer rate equation. The term $\boldsymbol{d n} / \boldsymbol{d} \boldsymbol{t}$ indicates decreasing rate or evaporation rate of liquid solvent in the reservoir, which is equal to vapor generation rate. Because the liquid surface area is constant, the vapor generation rate is proportional to the difference between the environmental and saturated vapor concentrations $\left(\boldsymbol{C}_{\boldsymbol{i}}-\boldsymbol{C}_{\boldsymbol{i}}{ }^{\mathrm{sat}}\right)$ from Eq.(1).

In the case of a multicomponent organic solvent system, Eq.(1) can be extended as follows:

$$
n \frac{d x_{i}}{d t}=k_{i} A\left(C_{i}-C_{i}^{*}\right)
$$

where $\boldsymbol{i}$ indicates the $\boldsymbol{i}$-th component in the solvent mixture, $\boldsymbol{x}_{\boldsymbol{i}}$ is the liquid molar fraction of component $\boldsymbol{i}$, and $C^{*}$ is the equilibrated vapor concentration.

If a system is an ideal solution, that is, there is no interaction between the solvents, the equilibrated vapor pressure or the equilibrated vapor concentration is proportional to the molar fraction in the liquid phase. However, an actual solvent mixture is usually not an ideal solution. In general, the equilibrated vapor pressure, $\boldsymbol{P}_{i}^{*}\left(=\boldsymbol{C}_{i}{ }^{*} \times 1.013 \times 10^{5} \mathrm{~Pa}\right)$, is shown as Eq.(3).

$$
\boldsymbol{P}_{i}^{*}=\gamma_{i} x_{i} \boldsymbol{P}_{i}^{\text {sat }}
$$

where $\gamma_{i}$ is the activity coefficient that depends on the combination of solvents, and $\boldsymbol{P}_{i}^{\text {sat }}$ is the saturated vapor pressure $\left(=C_{i}^{\text {sat }} \times 1.013 \times 10^{5} \mathrm{~Pa}\right)$.

Several equations are available for estimating $\boldsymbol{P}_{i}^{s a t}$. In this work, we used the following Antoine equation [5]

$$
\log _{10} \boldsymbol{P}^{s a t}=\boldsymbol{A}-\frac{\boldsymbol{B}}{\boldsymbol{C}+\theta}
$$

where $\boldsymbol{A}, \boldsymbol{B}$ and $\boldsymbol{C}$ are constants, and $\theta$ is the temperature $\left({ }^{\circ} \mathrm{C}\right)$.

For an ideal solution, $\gamma_{i}$ is equal to 1 , which is well known as Raoult's law. But for actual solutions, $\gamma_{i}$ is not equal to 1 . Several models have been proposed for the estimation of $\gamma_{i}$ such as the Margules equation, the Wilson equation, the UNIFAC equation, and so on[6]. In this study, the following UNIFAC equation was used for the estimation of $\gamma_{i}$.

$$
\ln \gamma_{i}=\ln \gamma_{i}^{C}+\ln \gamma_{i}^{R}
$$


The calculation of $\ln \gamma_{i}^{\mathrm{C}}$ and $\ln \gamma_{i}^{\mathrm{R}}$ are complicated, but they can be calculated for most organic solvent mixtures using given parameters that depend on chemical structures[4], so that the activity coefficient $\gamma_{i}$ can be estimated from Eq.(5).

From a mass balance, on the other hand, the generation rate can also be calculated from:

$$
-n \frac{d x_{i}}{d t}=\frac{Q C_{i}}{24.46}
$$

where $Q$ is the air flow rate ( $l / \mathrm{min})$.

By substituting Eq.(6) for Eq.(2),

$$
\frac{Q C_{i}}{24.46}=-\boldsymbol{k}_{i} A\left(C_{i}-C_{i}^{*}\right)
$$

From Eq.(7), $C_{i}$ is shown as follows.

$$
C_{i}=\frac{C_{i}^{*}}{\left(\frac{Q}{24.46 \boldsymbol{k}_{i} \boldsymbol{A}}+1\right)}
$$

In Eq.(8), $\boldsymbol{C}_{\boldsymbol{i}}^{*}$ is calculated from Eq.(3), and $\boldsymbol{Q}$ and $\boldsymbol{A}$ are known from the experimental condition. Therefore, the vapor concentration $C_{i}$ is calculated from Eq.(8), when the mass transfer coefficient, $\boldsymbol{k}_{\boldsymbol{i}}$, is given. A flow chart of the calculation procedure for the generated vapor concentration is shown in Fig. 2. In this study, EQUATRAN-G (Omega Simulations) was used for numerical calculation.

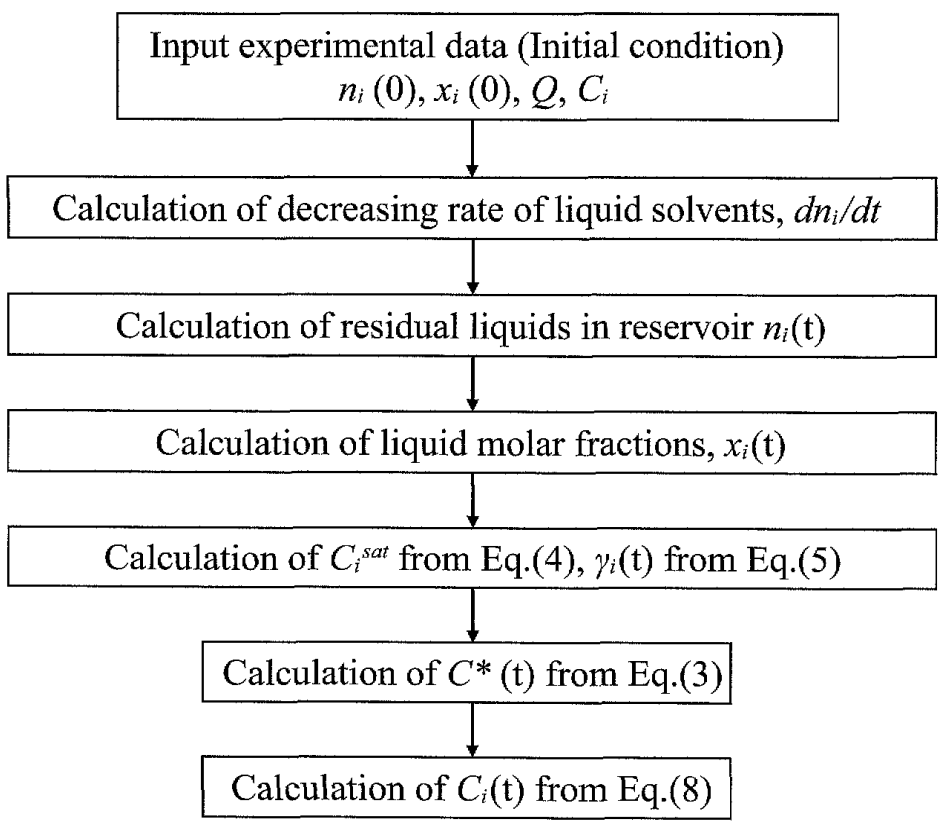

Fig. 2. Calculation procedure of generated vapor concentration. $(0)$ means initial condition and $(t)$ means the value at time $t$. 


\section{Results}

Figures 3 and 4 show the results of the ethyl acetate and toluene concentrations in the ethyl acetate-toluene system, respectively. The initial liquid molar fractions of ethyl acetate and toluene were the same, that is, 0.5 and 0.5 , respectively. The initial vapor concentration of ethyl acetate was about $12,000 \mathrm{ppm}$, and it increased slightly up to 30 minutes, and then it decreased with time. On the other hand, the initial toluene concentration was about 3,000 ppm, which is lower than ethyl acetate, then it increased gradually, and, finally, it became almost constant.

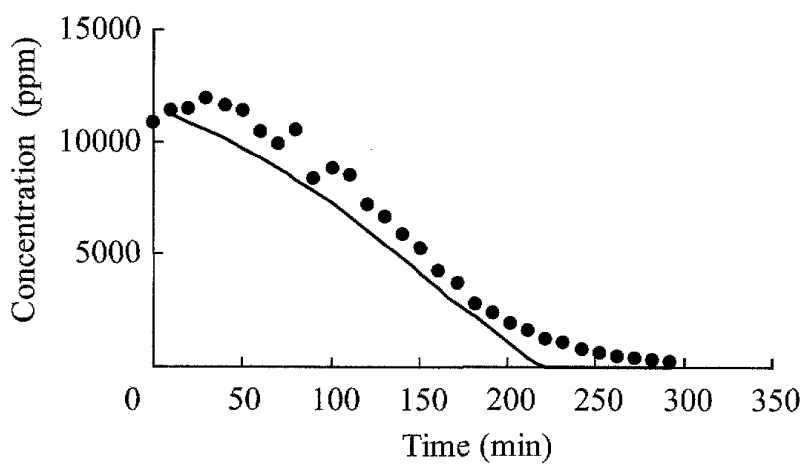

Fig. 3. Change in toluene concentration in the ethyl acetate-toluene system. Closed circles are experimental data and solid line is calculated line.

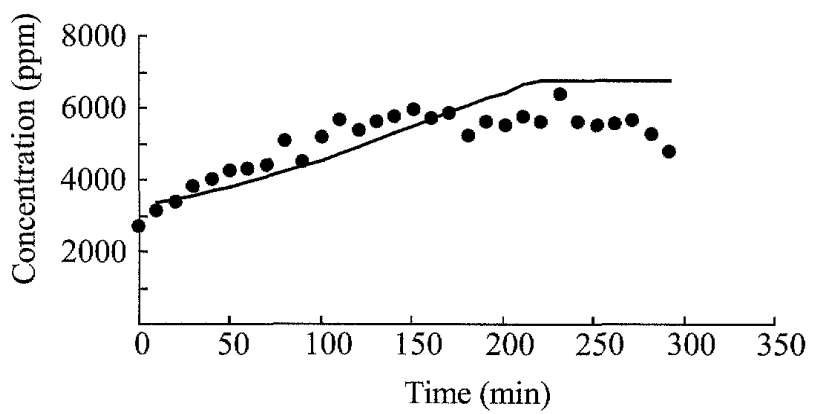

Fig. 4. Change in ethyl acetate concentration in the ethyl acetate-toluene system. Closed circles are experimental data and solid line is calculated line.

Figures 5 and 6 show the results of the methanol and toluene concentrations in the methanoltoluene system, respectively. The initial liquid molar fractions of methanol and toluene were 0.8 and 0.2 , respectively. The generated methanol vapor concentration was generally greater than the toluene. The initial methanol concentration was about $40,000 \mathrm{ppm}$, and it was almost constant or decreased slightly up to around 150 minutes, then it suddenly decreased remarkably. On the other hand, the toluene concentration was low at first and then tended to increase gradually.

The calculated values are also shown in the figures with solid lines. The mass transfer coefficient, $\boldsymbol{k}_{\boldsymbol{i}}$, was assumed to be $1.4 \times 10^{-6} \mathrm{~mol} / \mathrm{min} \cdot \mathrm{mm}^{2}$ for toluene and ethyl acetate, and 2.1 $\times 10^{-6} \mathrm{~mol} / \mathrm{min} \cdot \mathrm{mm}^{2}$ for methanol, based on the experimental results. The calculated vapor concentrations of both components of the ethyl acetate-toluene system were in relatively good agreement with the experimental ones. For the methanol-toluene system, the calculated values of the methanol concentrations had a similar tendency to the experimental values, but the timing of quick decrease in the calculated methanol vapor concentration was delayed compared with the experimental one. The calculated toluene concentration in the methanol-toluene system was a little higher, but it was in relatively good agreement with the experimental one, except in the initial 20-30 minutes. 


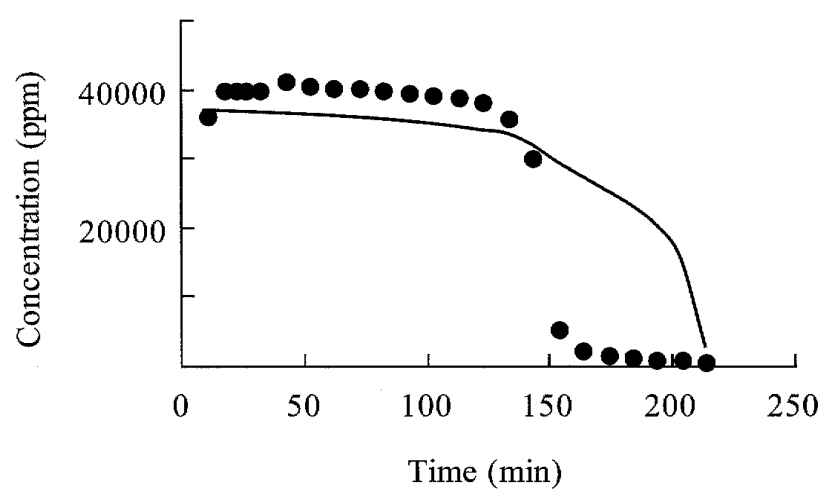

Fig. 5. Change in methanol concentration in the methanol-toluene system. Closed circles are experimental data and solid line is calculated line.

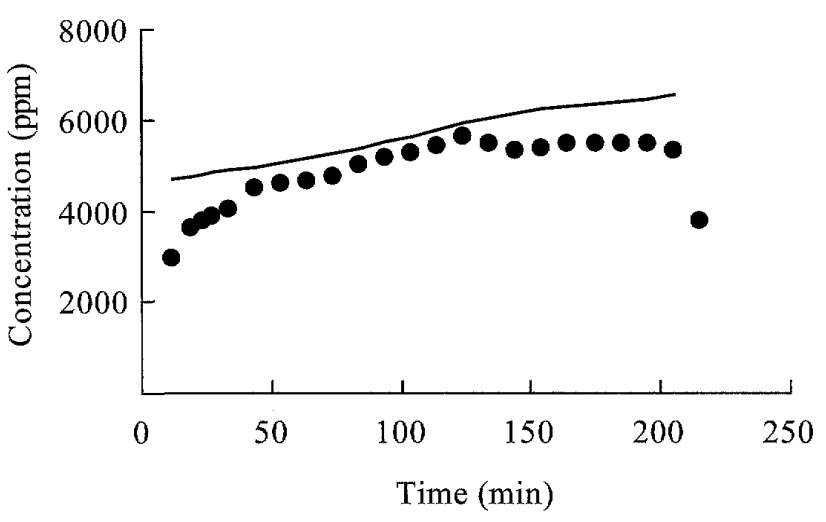

Fig. 6. Change in toluene concentration in the methanol-toluene system. Closed circles are experimental data and solid line is calculated line.

\section{Discussion}

Estimating or predicting organic vapor concentrations in work environments is important for the risk assessment of workplaces using organic solvents. In order to know the vapor concentration generated from multicomponent organic solvents, we studied the vapor-liquid equilibria experimentally and theoretically, and we have presented a satisfactory method of estimating the equilibrated vapor concentrations for a $2-4$ component solvents system [3,4]. Equilibrated vapor concentration means the maximum concentration under a given temperature. In the actual work environment, however, organic vapor concentrations never reach their equilibrated concentration because general workplaces are not closed but open to the outside, and the vapor concentration, $C_{i}$, is always smaller than $C_{i}{ }^{*}$. If this is the case, the vapor generation rate is proportional to the concentration difference, $\boldsymbol{C}_{i}^{*}-\boldsymbol{C}_{\boldsymbol{i}}$, according to Eq.(2).

In this study, we proposed a method of estimating the generated vapor concentrations using the theory of vapor-liquid equilibria and the theory of mass transfer rate. The generated vapor concentrations of a two component system, $C_{i}$, were calculated from Eq.(8). In order to calculate $\boldsymbol{C}_{\boldsymbol{i}}$ from Eq.(8), the mass transfer coefficient, $\boldsymbol{k}_{\boldsymbol{i}}$, should be known. In this study, we assumed $\boldsymbol{k}_{\boldsymbol{i}}$ was constant, and it was estimated from experimental data.

As shown in Figs. 3-6, the changes in calculated and experimental vapor concentrations were similar, but they were not the same. In Fig. 3, the calculated ethyl acetate concentration decreased to zero at about 220 minutes. However, the vapor concentration did not fall into null concentration at this time but gradually decreased up to 300 minutes. This result suggests that the calculated liquid ethyl acetate had evaporated almost completely within 220 minutes, but in actual conditions, an amount of liquid ethyl acetate remained in the reservoir even at 220 minutes or later. In Fig. 4, on the other hand, the toluene concentration tended to increase from the beginning gradually, and then became almost constant. The reason why the toluene concentration increased is that the toluene molar fraction in the liquid phase increased with time because the evaporation rate of ethyl acetate is larger than toluene. When the ethyl acetate had completely 
evaporated, only toluene remained in the reservoir. If this is the case, the toluene vapor concentration would be constant until the liquid toluene evaporates completely.

The experimental methanol vapor concentration of the methanol-toluene system was generally high, but it decreased quickly at around 150 minutes (Fig. 5). The calculated methanol concentration also decreased but the beginning time of quick decrease in the methanol vapor concentration was extended. This quick reduction in the methanol concentration indicates that the liquid methanol had evaporated completely at this time and only the toluene remained in the liquid phase. Because the calculated vapor concentration was generally lower, and therefore, the amount of evaporated solvent was slightly smaller than experimental ones (Fig. 5), the calculated liquid methanol still remained at around 150 minutes, and a quick decrease of methanol concentration occurred, but the time was delayed.

The shapes of the experimental vapor concentration curves in Fig. 3 and 5 are different. The ethyl acetate concentration decreased linearly. On the other hand, the methanol concentration kept constant for 150 minutes, and then decreased quickly. This difference can be explained as follows.

An ethyl acetate-toluene system can be regarded as an ideal solution. In this case, the equilibrated vapor concentration was proportional to the liquid molar fraction. In Fig. 3, because the liquid molar fraction of ethyl acetate decreased, the ethyl acetate vapor concentration also decreased in proportion to the liquid molar fraction.

On the other hand, the vapor-liquid equilibria of the methanol-toluene system are much different from an ideal solution [2]. For example, even if the liquid methanol fraction was only $10 \%$ and the toluene fraction was $90 \%$, the equilibrated methanol molar fraction in the vapor phase would be greater than $80 \%$, and it would be almost constant when the liquid methanol molar fraction was between $10-80 \%[3,4]$. In Fig. 5, the initial liquid molar fraction of methanol was $80 \%$, and the vapor concentration of methanol was about $40,000 \mathrm{ppm}$, which was much greater than that of toluene. Because methanol is more volatile than toluene, the methanol generation rate is greater than toluene. Therefore, the methanol fraction in the liquid phase decreased with time but the equilibrated vapor concentration did not change remarkably while the liquid methanol fraction was greater than $10 \%$. When the methanol fraction in the liquid phase becomes less than $10 \%$, the methanol vapor concentration decreases quickly, depending on the decreasing methanol liquid molar fraction. If the experimental and calculated vapor concentrations were slightly different, the total amounts of generated vapors were also different. As a result, the remaining liquid molar fractions in the reservoir between the experimental and calculated values were also slightly different. This slight difference in liquid molar fraction may cause a large difference in the concentration curves. Therefore, it is difficult to estimate vapor concentration accurately for non-ideal solution systems, such as a methanol-toluene system.

The proposed model could roughly estimate the generated vapor concentration from the twocomponent organic solvents evaporated from a liquid reservoir continuously.

Using this model, we can predict the generated vapor concentration of multicomponent organic vapors in work environments. This method can be applied for predicting work environments in advance of actual work, which gives useful information for risk assessment of workplaces using mixtures of organic solvents. In this study, we assumed that the mass transfer rate was 
constant and it was determined based on the experimental data. However, the mass transfer rate may change depending on the amount of solvents in the reservoir. For more accurate calculation, more and more experimental data should be accumulated and a better method of estimating the mass transfer coefficient should be developed.

\section{Acknowledgment}

The authors thank Ms.Kumika Umezaki for technical help. This research was partly supported by the Japan Society for the Promotion of Science, Gants-in-Aid for Scientific Research (C) (20590623).

\section{References}

1. Inoue $\mathrm{T}$, Ikeda $\mathrm{M}$, Ogata $\mathrm{M}$ et al (1984): A Nationwide survey on the use of organic solvents in Japan. Jpn J Ind Health 26: 518-538 (in Japanese)

2. Kohriyama K, Hori H, Yamada N, Inoue N \& Kohno K (1991): Vapor-liquid equilibria for methanoltoluene system: high vapor concentration of methanol. J UOEH 13: 25-28

3. Hori H \& Tanaka I (1998): Equilibrated vapor concentrations for bicomponent organic solvents. J Occup Health 40: 132-136

4. Ishidao T, Ishimatsu S \& Hori H (2004): Vapor-liquid equilibria for multicomponent organic vapors. J UOEH 26: 327-335 (in Japanese)

5. Keil CB \& Nicas M (2003): Predicting room vapor concentrations due to spills of organic solvents. AIHA J 64: 445-454

6. Takamatsu T, Akihata T, Inoue H et al (1988): Antoine equation. Kagaku Kogaku Binran 5th. The Society of Chemical Engineers, Japan (ed). Maruzen, Tokyo pp18-27 (in Japanese)

7. Poling E, Prausnitz M \& O'Connell P (2001): Fluid Phase Equilibria in multicomponent systems. The Properties of Gases and Liquids 5th ed. McGraw Hill, New York pp 8.1-8.204 
2 成分系混合有機溶剤の蒸発に伴う環境気中濃度の経時変化の予測法

保利 一, 石田尾 徹, 石松 維世

産業医科大学＼cjkstart産業保健学部 作業環境計測制御学講座

要旨：産業現場で使用される有機溶剂の多くは, 混合有機溶剂である，有機溶剂は, 蒸気圧 や極性などが異なるため, 混合したときの液相の組成と気中の蒸気濃度の組成比は, 一般に異なる。また, 蒸発に伴って液相中の組成も変化するので, 蒸気濃度も経時的 に変化する．そこで容器内に入れた 2 成分の混合有機溶剤が連続的に㸃発したときの 気中の濃度変化を調べるとともに, 気中の蒸気濃度を予測するモデルを作成した，直 径 $3 \mathrm{~cm}$, 高さ $3 \mathrm{~cm}$ の円筒形の容器に 2 種類の溶剂を所定量入れ, 直径 $10 \mathrm{~cm}$, 高さ $15 \mathrm{~cm}$ の密閉したガラス容器内に静置した。流量 $150 \mathrm{ml} / \mathrm{min}$ の空気をガラス容器内に導入 し, 容器を出る芣気をオートガスサンプラーにより一定時間間隔でサンプリングし， 水素炎イオン化検出器 (FID) 付ガスクロマトグラフで濃度を計測した．溶剤は酢酸エ チルートルエン系抢よびメタノールートルエン系とした，揮発性の高い溶郕(酢酸エ チルまたはメタノール）の濃度は最初は高く,時間とともに減少する傾向が見られた， 一方, 揮発性の低い溶剂（トルエン）は最初低く，時間とともに上昇した。気液平衡理 論および物質移動速度論を用いて, 発生する蒸気濃度の推算モデルを作成し, 実験值 と比較検討した結果, 両者は実験值と比較的良好な一致を示した。

キーワード： 混合有機溶剂, 気液平衡, 活量係数, 物質移動速度.

J UOEH（産業医大誌）32（4）：293 - 302（2010） 